\title{
Knowledge Relationship About Lactation Management With Maternal Behavior In Breastfeeding
}

\author{
Hasliah $^{1}$, A.Nurlaela Amin ${ }^{2 *}$, Fitriani $^{3}$ \\ ${ }^{1,}$ Nursing Student, Stikes Panrita Husada Bulukumba, Indonesia \\ ${ }^{2,3}$ Departement of Nursing, Stikes Panrita Husada Bulukumba, Indonesia \\ *Corresponding author: A.Nurlaela Amin \\ Email: alleaalle@gmail.com
}

\begin{abstract}
ABSTRAC
The background of this study is that breastfeeding behavior is an active act of a mother in exclusive breastfeeding that is without additional food from the baby born to 6 months of age. The purpose of the research is the known relationship of maternal knowledge about lactation management with maternal behavior in breastfeeding at the Puskesmas Kajang Kecematan Kajang Bulukumba Regency. The research method conducted is descriptive correlation research with a Cross-Sectional approach. Data collection using questionnaires. The number of respondents to 47 mothers had babies 6-12 months with simple random sampling technique. The results showed that using the chi-square statistical test obtained a value of $\rho=$ $0.028<\alpha=0.05$. Then there is a difference in proportion between maternal knowledge of lactation management and maternal behavior in breastfeeding or other words. There is a relationship between maternal knowledge of lactation management and maternal behavior in breastfeeding. Conclusion and Advice are that there is a knowledge relationship about lactation management with maternal behavior in breastfeeding in public Health Kajang districts kajang Bulukumba regency. The research results can add science and can be used as additional libraries in the field of science for educational institutions Stikes Panrita Husada Bulukumba.
\end{abstract}

Keywords: Knowledge, Lactation Management, Behavior, Exclusive Breast Milk 


\section{PENDAHULUAN}

Pengetahaun ibu tentang manajemen laktasi adalah pemahaman ibu tentang ASI Ekslusif yaitu tidak hanya memberikan ASI saja pada bayi tetapi lebih luasnya ibu memahami, cara memerah, menyimpan dan memberikan ASI dan lain-lain (Alfidayana, 2017). Berdasarkan data UNICEF (2013), sebanyak 136,7 juta bayi lahir diseluruh dunia dan hanya 32,6\% dari mereka yang disusui secara eksklusif dalam 6 bulan pertama. Bayi yang tidak diberi ASI Eksklusif di Negara industry lebih besar meninggal dari pada bayi yang diberikan ASI Eksklusif, sementara di Negara berkembang hanya 39\% ibu-ibu yang memberikan ASI Eksklusif. Menurut data WHO (2016), cakupan ASI Eksklusif di seluruh dunia hanya sekitar 36\% selama periode 2007-2014 (Kudadiri, 2018).

Berdasarkan data Riskesdas 2018 pemberian ASI pada bayi umur 0-5 bulan di Indonesia sebanyak 37,3\% ASI eksklusif, 9,3\% ASI parsial, dan 3,3\% ASI predominan. Berdasarkan tempat tinggal, persentase penduduk kurang dari 6 bulan yang pernah diberi ASI tahun 2017 sebanyak $26,4 \%$ di daerah perkotaan dan $25,1 \%$ di daerah perdesaan. Hal tersebut sejalan dengan hasil Riskesdas 2018 yaitu proporsi ASI eksklusif pada bayi usia 0-5 bulan lebih banyak di perkotaan $(40,7 \%)$ dibandingkan perdesaan $(33,6 \%)$. Provinsi dengan proporsi tertinggi pemberian ASI pada bayi umur 0-5 bulan tahun 2018 adalah Provinsi Kepulauan Bangka Belitung (56,7\%), sedangkan provinsi dengan proporsi terendah adalah Provinsi Nusa Tenggara Barat (20,3\%) (Sakti, 2018).

Menurut data Dinkes Provensi Sulawesi Selatan (2016), kriteria bayi 0-6 bulan mendapat ASI eksklusif yang diberi ASI saja tanpa makanan lain atau cairan lain berdasarkan recall 24 jam, dari pelaporan Kabupaten/Kota sebesar $68 \%$ dan belum mencapai angka yang ditargetkan $(83 \%)$ dan mengalami penurunan dari tahun sebelumnya yaitu 71,50\% di tahun 2015, 68,45\% di tahun 2014 dan 75\% di tahun 2013. Rata-rata prevalensi capaian ASI Eksklusif di 24 Kabupaten/Kota Provinsi Sulawesi Selatan sebear 42\%. Kabupaten yang paling tinggi capaian targetnya adalah kabupaten Soppeng 81,9\% dan yang paling rendah adalah kota Pare-Pare 48\% (KESEHATAN, 2018).

Berdasarkan data yang di peroleh dari Dinas Kesehatan Kabupaten Bulukumba didapatkan hasil, Angka cakupan ASI Eksklusif tahun 2019 dari jumlah bayi direcall 18,787 dan jumlah bayi masih ASI Eksklusif sebanyak 12,01 (63.93\%) bayi. Di Kecematan Kajang khususnya di Puskesmas Kajang sebanyak 20 bayi, yang di beri ASI Eksklusif sebanyak 19 bayi. Berdasarkan survey awal peneliti di wilayah kerja Puskesmas Kajang bahwa ibu tidak memberikan ASI secara Eksklusif. Hal ini disebabakan oleh beberapa factor seperti rendahnya pengetahuan ibu dan keluarga magenai manfaat ASI, cara menyusui yang benar, 
kurangnya ASI yang keluar pada hari pertama setelah kelahiran, umur ibu yang masih mudah sehingga belum bisa menyusui secara maksimal, dan kurangnya waktu karena sibut dengan bekerja sebagai petani, pedagang dan pekerja swasta sehingga kurang kesempatan untuk memberikan ASI kepada bayinya secara optimal.

Penelitian yang sama juga dilakukan oleh Claratika Ayu Mawarni (2017) tentang Hubungan antara pengetahuan ibu yang bekerja tentang manajemen laktasi dengan perilaku dalam pemberian ASI di wilayah puskesmas karangjati hasil penelitian ini didapatkan ada hubungan pengetahuan ibu yang bekerja dengan perilaku dalam pemberian ASI di wilayah puskesmas Karangjati. Berdasarkan urian latar belakang diatas, maka peneliti merasa tertarik untuk melakukan penelitian dengan judul "Hubungan Pengetahuan Tentang Manajemen Laktasi dengan Perilaku Ibu dalam Pemberian ASI di Puskesmas Kajang Kecematan Kajang Kabupaten Bulukumba",

\section{METODE PENELITIAN}

\section{Desain Penelitian}

Sesuai dengan masalah penelitian deskriptif correlation dengan pendekatan Cross Sectional dan tujuan penelitian ini guna menjelaskan penelitian dengan bermacam-macam hubungan(Sugiyono, 2017). Penelitian ini focus antara variabel dan analisa untuk menguji hipotesa. Karakteristik dari penelitian ini adalah penggambaran dengan mengumpulkan data dari pengetahui ibu bekerja tentang manajemen laktasi, dukungan tempat kerja dan perilaku ibu dalam pemberian ASI. Dan hasil dari analisanya untuk mengetahui hubungan dari mereka (Sugiyono, 2017).

\section{Populasi dan Sampel}

Populasi dalam penelitian ini adalah semua ibu mempunyai bayi usia 6-12 bulan sebanyak 132 bayi. Sampel dalam Penelitian ini adalah Ibu yang mempunyai bayi 6-12 bulan. Berdasarkan perhitungan didapatkan besar saampel sebanyak 47 responden.

\section{Instrument Penelitian}

Pengetahuan ibu tentang manajemen laktasi menggunakan alat ukur Kuisioner dengan skala Guttman, dengan nilai 1 untuk jawaban benar, 0 untuk jawaban salah. Sedangkan Perilaku ibu dalam pemberian ASI menggunakan skala Guttman, kategori Baik jika memberikan ASI Eksklusif, kurang baik jika tidak memberikan ASI Eksklusif.

\section{HASIL PENELITIAN}

Berdasarkan table 1 dapat diketahu bahwa responden yang terbanyak pada penelitian ini adalah responden usia remaja sebanyak 31 orang $(66,0 \%)$, responden yang sedikit dewasa Akhir sebanyak 2 orang (4,3\%). Berdasarkan table diatas dapat diketahui bahwa responden 
yang terbanyak pada penelitian ini adalah responden orang tua dengan riwayat pendidikan SMA sebanyak 25 orang $(53,2 \%)$ dan responden yang paling sedikit orang tua yang S1 atau yang bekerja 2 orang $(4,3 \%)$. Berdasarkan table diatas dapat diketahui bahwa responden yang terbanyak pada penelitian ini adalah orang tua yang tidak bekerja sebanyak 45 orang $(95,7 \%)$ dan yang paling sedikit orang tua yang bekerja sebanyak 2 orang $(4,3 \%)$.

Table 1. Distribusi Frekuensi Responden Berdasarkan Umur Orang Tua, Pendidikan, Pekerjaan,

\begin{tabular}{ccc}
\hline Karakteristik & Frekuensi (f) & Persentase (\%) \\
\hline Umur orang tua & & \\
Remaja (17 - 25) & 31 & 66,0 \\
Dewasa awal (26 - 35) & 14 & 29,8 \\
Dewasa akhir (36 - 45) & 2 & 4,3 \\
Pendidikan & 9 & 19,1 \\
SD & 11 & 23,4 \\
SMP & 25 & 53,2 \\
SMA & 2 & 4,3 \\
S1 & & \\
Pekerjaan & 45 & 95,7 \\
IRT & 2 & 4,3 \\
Guru & 47 & 100,0 \\
\hline Jumlah & & \\
\hline
\end{tabular}

Berdasarkan table 2dapat diketahui bahwa responden yang terbanyak dalam penelitian ini adalah jenis kelamin laki-laki 24 orang $(51,1 \%)$ dan jenis kelamin yang sedikit perempuan 23 orang $(48,9 \%)$. Berdasarkan tabel diatas dapat diketahui bahwa respponden yang terbanyak dalam penelitian ini adalah umur anak 12 bulan sebanyak 12 orang $(25,5 \%)$ dan yang paling sedikit umur 5 bulan sebanyak 1 orang $(2,1 \%)$.

Table 2. Distribusi Frekuensi Responden Berdasarkan Jenis kelamin anak dan umur anak

\begin{tabular}{ccc}
\hline Karakteristik & Frekuensi (f) & Persentase (\%) \\
\hline Jenis kelamin & & \\
Perempuan & 23 & 48,9 \\
Laki-laki & 24 & 51,1 \\
Umur Anak & & \\
6 bulan & 6 & 12,8 \\
7 bulan & 5 & 10,6 \\
8 bulan & 2 & 8,5 \\
9 bulan & 8 & 17,0 \\
10 bulan & 2 & 4,3 \\
11 bulan & 8 & 17,0 \\
12 bulan & 12 & 25,5 \\
\hline Jumlah & 47 & 100,0 \\
\hline
\end{tabular}


Berdasarkan tabel 3 dapat diketahui bahwa pengetahuan ibu tentang manajemen laktasi dari 47 responden yang memiliki pengetahuan yang baik sebanyak 25 orang $(53,2 \%)$, dan yang memliki tingkat pengetahuan kurang sebanyak 7 orang (14,9\%). dapat diketahui bahwa responden yang terbanyak pada penelitian ini adalah pemberian ASI eksklusif sebanyak 33 orang $(70,2 \%)$ dan yang tidak diberikan ASI eksklusif sebanyak 14 orang (29,8\%).

Tabel 3. Distribusi Frekuensi Responden Berdasarkan Pengetahuan Manajemen Laktasi dan Pemberian Asi Eksklusif Pada Anak

\begin{tabular}{ccc}
\hline $\begin{array}{c}\text { Pengetahuan manajemen } \\
\text { laktasi }\end{array}$ & Frekuensi (f) & Persentase (\%) \\
\hline Baik & 25 & 53,2 \\
Cukup & 15 & 31,9 \\
Kurang & 7 & 14,9 \\
\hline Pemberian ASI Eksklusif & Frekuensi (f) & Persentase (\%) \\
\hline Baik & 33 & 70,2 \\
Kurang baik & 14 & 29,8 \\
\hline Total & $\mathbf{4 7}$ & $\mathbf{1 0 0 , 0}$ \\
\hline
\end{tabular}

Berdasarkan tabel 4. dapat dilihat bahwa ibu yang memliki pengetahuan baik yang memiliki perilaku memberikan ASI baik sebanyak 21 orang $(63,6 \%)$ dan ibu yang memiliki pengetahuan baik yang memiliki perilaku pemberikan ASI kurang baik yaitu 4 orang $(28,6 \%)$. Sedangkan ibu yang memiliki pengatahuan cukup kurang yang memliki perilaku pemberian ASI baik sebanyak 12 orang $(36,4 \%)$ dan ibu yang memliki pengetahuan cukup kurang yang memliki perilaku pemberian ASI kurang baik sebanyak 10 orang $(71,4 \%)$. Sehingga dapat di simpulkan bahwa ada hubungan pengetahuan tentang manajemen laktasi dengan perilaku ibu dalam pemberian ASI. Berdasarkan hasil analisa menggunakan uji statistic chi square diperoleh nilai $\rho=0,028<\alpha=0,05$. maka ada perbedaan proporsi antara pengetahuan ibu tentang manajemen laktasi dengan perilaku ibu dalam pemberian ASI atau denagn kata lain ada hubungan antara pengetahuan ibu tentang manajemen laktasi dengan perilaku ibu dalam pemberian ASI.

Tabel 4. Hubungan Pengetahuan Tentang Manajemen Laktasi Dengan Perilaku Ibu Dalam Pemberian ASI Eksklusif

\begin{tabular}{|c|c|c|c|c|c|c|c|}
\hline \multirow{3}{*}{ Pengetahuan } & \multicolumn{6}{|c|}{ Perilaku ibu dalam pemberian ASI } & \multirow{3}{*}{ PValue } \\
\hline & \multicolumn{2}{|c|}{ Baik } & \multicolumn{2}{|c|}{ Kurang baik } & \multicolumn{2}{|c|}{ Total } & \\
\hline & $\mathrm{N}$ & $\%$ & $\mathrm{n}$ & $\%$ & $\mathbf{n}$ & $\%$ & \\
\hline Baik & 21 & 63.6 & 4 & 28,6 & 25 & 53,2 & \\
\hline Cukup Kurang & 12 & 36,4 & 10 & 71,4 & 22 & 46,8 & 0.028 \\
\hline Jumlah & 33 & 100.0 & 14 & 100.0 & 47 & 100.0 & \\
\hline
\end{tabular}




\section{PEMBAHASAN}

a. Pengetahuan tentang manajemen laktasi

Berdasarkan hasil penelitian dapat diketahui bahwa pengetahuan ibu tentang manajemen laktasi dari 47 diatas dapat diketahui bahwa pengetahuan ibu tentang manajemen laktasi dari 47 responden yang memiliki pengetahuan yang baik sebanyak 25 orang $(53,2 \%)$, dan yang memliki tingkat pengetahuan kurang sebanyak 7 orang (14,9\%). Pengetahuan ibu tentang manajemen laktasi adalah pemehaman ibu tentang ASI Eksklusif yaitu tidak hanya memberikan ASI saja pada bayi tetapi lebih luasnya ibu memahami cara memerah, menyimpan dan memberikan ASI dan lain-lain. Tingkat pengetahuan responden tersebut dipengaruhi oleh beberapa factor, antara lain tingkat pendidikan dan pekerjaan.

Menurut (Rizki Ramadhan, 2015), pengetahuan sangat erat hubunganya dengan pendidikan, diharapkan dengan pendidikan yang tinggi akan memperluas pengetahuan dan mempermudah memperoleh informasi sehingga akan berpengaruh terhadap perilakunya dan dalam hal ini adalah perilaku ibu dalam pemberian ASI, hal yang sama disampaikan oleh (Asri, Mulyono, \& Khasanah, 2020) bahwa tingkat pengetahuan yang baik akan mempengaruhi seseorang dalam berperilaku.

Hasil penelitian in sejalan dengan Traina Sari, Sri Mudyati Ningsi Dan Lairs "hubungan pengetahuan tentang manajemen laktasi dengan sikap ibu post partum dalam proses di ruang bersalin RS panti waluya malang" menunjutkan hail bahwa pengetahuan tentang manajemen laktasi didpatkan hail bahwa dari 23 responden yang diteliti sebanyak 9 responden $(39,1 \%)$ berpengetahuan cukup, 8 responden $(34,8 \%)$ berpengetahuan kurang dan 6 responden $(26,1 \%)$ berpengetahuan baik. Hal in karena kurangnya pengetahuan yang didapatkan tentang manajemen laktasi (Sari, Ningsih, \& Lasri, 2018).

Menurut asumsi peneliti ada pengetahuan ibu untuk memporoleh pengetahuan terkait dengan pemberian ASI Eksklusif tentunya akan mencari informasi sebanyakbanyaknya melelui media cetak,elektronik maupun petugas kesehatan tentang hal-hal yang berkaitan dengan manajemen laktasi sehingga ibu tersebut dapat mengaplikasikan pengetahuan untuk dapat mendukung pemberian ASI pada bayinya.

b. Perilaku ibu dalam pemberian ASI

Berdasarkan hasil penelitian dari 47 responden menunjukkan bahwa ibu yang memberikan ASI eksklusif kepada bayinya sebanyak 33 orang (70,2\%) dan ibu yang tidak memberikan ASI Eksklusif pada bayinya sebanyak 14 orang (29,8\%). 
ASI eksklusif dalam penelitian ini adalah pemberian Air susu ibu saja tanpa tambahan cairan atau makanan lain. Karena manfaat ASI disini dapat dilihat dari beberapa aspek yaitu aspek gizi, aspek imunologi, aspek psikologi, aspek kecerdasan, neurologis, dan ekonomis. (Dewi, 2015). Adapun manfaat ASI merupakan kegiatan menyenangkan bagi ibu dan bayi, sekaligus memberikan manfaat tak terhingga bagi sang buah hati. Bayi dapat mendapatkan nutrisi dan enzim terbaik yang dibutuhkan sehi ngga memenuhi nutrisi anak, bayi mendapatkan zat kekebalan tubuh serta perlindungan dan kehangatan melalui kontak kulit dengan ibunya sehingga anak mendapatkan kekebalan tubuh dan tidak mudah terkena penyakit.

Hasil penelitian ini sesuai dengan penelitian yang dilakukan oleh Aureliya Huiagaol "Hubungan Pengetahuan Ibu Tentang Manajemen Laktasi Dengan Pemberian Asi Eks Klusif Di Rumah Sakit Imelda Pekerja Indonesia” menunjukkan hasil bahwa sebagian besar ibu yang memberikan ASI eksklusif sebanyak 39 orang $(97,5 \%)$ dan tidak memberikan ASI eksklusif Sebanyak 1 oarng (2,5\%). Pada ibu dengan jumlah paritas satu seringkali menemui masalah yang sering muncul adalah bayinya, putting susu lecet akibat kurang pengalaman yang dimiliki atau belum siap menyusui secara fisiologis.

Menurut asumsi peneliti terkait kebanyakan orang tua yang pekerjaannya IRT, karena ibu yang bekerja dengan yang tidak bekerja tingkat stressnya berbeda sehingga ibu yang tidak bekerja memiliki ketenangan jiwa dan pikiran sehingga dapat mempengaruhi produksi ASI. Sedangkan ibu yang tidak memberikan ASI eksklusif penyebab utamanya adalah adanya kepercayaan dan kebiasaan dari orang tua tentang memberi air beras, susu dan madu pada anaknya sesaat setelah lahir. Selain itu kebanyakan ASI tidak keluar pada hari petama setelah melahirkan sehingga terpaksa memberikan anaknya cairan lain seperti susu formula sebagai pengganti ASI. Sementara itu terdapat pula ibu yang terlalu cepat memberikan makanan pendamping ASI kepada anaknya sehingga menggagalkan pemberian ASI eksklusif dan juga ibu mengalami tingkat stress, pikiran tertekan, tidak tenang, sedih, dan tegang, sehingga produksi ASI akan terganggu.

c. Hubungan pengetahuan tentang manajemen laktasi dengan perilaku pemberian ASI

Hasil penelitian menunjukan bahwa dari 47 dapat dilihat bahwa ibu yang memliki pengetahuan baik yang memiliki perilaku memberikan ASI baik sebanyak 21 orang $(63,6 \%)$ dan ibu yang memiliki pengetahuan baik yang memiliki perilaku 
pemberikan ASI kurang baik yaitu 4 orang $(28,6 \%)$. Sedangkan ibu yang memiliki pengatahuan cukup kurang yang memliki perilaku pemberian ASI baik sebanyak 12 orang $(36,4 \%)$ dan ibu yang memliki pengetahuan cukup kurang yang memliki perilaku pemberian ASI kurang baik sebanyak 10 orang $(71,4 \%)$. Sehingga dapat di simpulkan bahwa ada hubungan pengetahuan tentang manajemen laktasi dengan perilaku ibu dalam pemberian ASI. Berdasarkan hasil analisa menggunakan uji statistic chi square diperoleh nilai $\rho=0,028<\alpha=0,05$. maka ada perbedaan proporsi antara pengetahuan ibu tentang manajemen laktasi dengan perilaku ibu dalam pemberian ASI atau denagn kata lain ada hubungan antara pengetahuan ibu tentang manajemen laktasi dengan perilaku ibu dalam pemberian ASI.

Hasil penelitian ini sejalan dengan Hilarius Holan Woja dan Sri Mudayati, membuktikan bahwa ada hubungan tingkat pengetahuan tentang manajemen laktasi dengan perilaku ibu dalam pemberian ASI di Posyandu seruni Tlogomas kecematan Lowokwaru kota malang. Hasil penelitian ini juga sejalan dengan Herry dan Eva Nurafiah yang melakukan penelitian "pengetahuan ibu tentang manajemen laktasi dengan perilaku pemberian ASI Eksklusif” menujukan hasil bahwa ada hubungan yang bermakna antara pengetahuan manajemen laktasi dengan perilaku pemberian ASI.

Menurut asumsi peneliti, temukannya hubungan antara pengetahuan ibu tentang manajemen laktasi dengan perilaku ibu dalam pemberian ASI berdasarkan hail observasi yang berpengetahuan baik dengen perilaku tidak ekslusiif terkadang masih menggunakan susu formula karena keterbatasan pengetahuan tentang ASI perah, sedangkan yang perpengetahuan baik dengan perilaku eksklusif bisa tau mengenai asi perah.

\section{KESIMPULAN DAN SARAN}

Ada hubungan pengetahuan tentang manajemen laktasi dengan perilaku ibu dalam pemberian ASI di puskesmas kajang kecematan kajang kabupaten bulukumba. Disarankan kepada pihak pemerintah untuk meningkatkan penyuluhan kepada kader dan ibu-ibu tentang pentingnya ASI eksklusif.

\section{DAFTAR PUSTAKA}
ALFIDAYANA, R. (2017). HUBUNGAN PENGETAHUAN IBU BEKERJA TENTANG MANAJEMEN LAKTASI DAN DUKUNGAN TEMPAT KERJA DENGAN PERILAKU IBU DALAM PEMBERIAN ASI DI WILAYAH KERJA PUSKESMAS PEMBANTU (PUSTU) AMPLAS MEDAN RIZA.

Asri, Mulyono, S., \& Khasanah, U. (2020). Pengaruh Pelatihan Kader Posbindu Terhadap 
Perilaku Deteksi Dini Hipertensi Pada Usia Dewasa. Jurnal Kesehatan Panrita Husada, 5(1 SE-Articles). https://doi.org/10.37362/jkph.v5i1.315

Dewi, D. P. (2015). STATUS STUNTING KAITANNYA DENGAN PEMBERIAN ASI EKSKLUSIF PADA BALITA DI KABUPATEN GUNUNG KIDUL. Medika Respati, $X, 60-64$.

KESEHATAN, D. (2018). RENCANA KERJA TAHUN 2018 DINAS KESEHATAN. RENCANA KERJA TAHUN 2018 DINAS KESEHATAN PROVENSI SULAWESI SELATAN.

Kudadiri, H. (2018). World Health Organization. Pengaruh Pijat Oksitosin Terhadap Peningkatan Produksi ASI Pada Ibu Postpartum Di Klinik Kurnia Kecematan Medan Denai Tahun 2018, (1).

Rizki Ramadhan. (2015). Rizki Ramadhan. Hubungan Tingkat Pengetahuan Tentang Manajemen Laktasi Dengan Keberhasilan Pemberian ASI Eksklusif Di Kecamatan Kemangkon Kabupaten Purbalingga, 1-9.

Sakti, E. S. (2018). Infodatin pusat data dan informasi kementerian kesehatan RI. Menyusui Sebagai Dasar Kehidupan Tema Pekan ASI Sedunia, 1-7 Agustus 2018 S, 1-7.

Sari, T., Ningsih, S. M., \& Lasri. (2018). hubungan pengetahuan tentang manajemen laktasi dengan sikap ibu post partum dalam proses menyusui di ruangan bersalin Rs Panti Waluya Malang, 722.

Sugiyono, P. D. (2017). Metedologi Penelitian Kuantitatif, Kualitatif dan R \& D (26th ed.). Bandung: ALFABETA, cv. 